\title{
Preweaning Food Intake Influences the Adiposity of Young Adult Baboons
}

\author{
Douglas S. Lewis, “ Helen A. Bertrand,‡ C. Alex McMahan, $\S$ \\ Henry C. McGill, Jr.,"§ Kenneth D. Carey," and Edward J. Masoroł \\ *Department of Physiology and Medicine, Southwest Foundation for Biomedical Research, and Departments of $\ddagger P h y s i o l o g y$ \\ and §Pathology, University of Texas Health Science Center, San Antonio, Texas 78284
}

\begin{abstract}
The hypothesis that preweaning nutrition influences adult fat cell number and adiposity was tested in baboons. Newborn baboons were fed Similac formulas with caloric densities of $\mathbf{4 0 . 5}$ kcal (underfed), $67.5 \mathrm{kcal}$ (fed normally), and $94.5 \mathrm{kcal}$ (overfed) per $100 \mathrm{~g}$ formula. From weaning (16 wk) until necropsy at $5 \mathrm{yr}$ of age all baboons were fed the same diet. At necropsy, fat cell number and fat cell size in 10 fat depots were measured. Female baboons overfed as infants had markedly greater fat depot mass, primarily because of fat cell hypertrophy, than normally fed or underfed females. Overfed male baboons had a greater fat mass in 4 of 10 depots compared with males underfed or fed normally as infants. Underfeeding did not affect body weight, nor adipose mass of either sex. The results show that infant food intake does not have a major influence on the fat cell number of young adult baboons.
\end{abstract}

\section{Introduction}

Obesity is a multifactorial condition that has been described recently as a disease (1). Infant overnutrition and the resulting weight gain have been proposed by many (2-7) but not all investigators (8) as factors leading to obesity ("fat babies become fat adults"). A suggested mechanism by which infant overnutrition may lead to obesity is that excessive food intake at this stage of life leads to fat cell hyperplasia $(9,10)$. The increased number of fat cells is hypothesized to predispose the individual to obesity throughout life. Consistent with this view are data showing that childhood obesity is often characterized by increased fat cell number (9-15).

High caloric intake in both preweaning $(16,17)$ and adult $(18,19)$ rats and mice can increase fat cell number. However, there is no convincing evidence that such is the case for humans or other primates. It has not been possible to estimate accurately fat cell number in humans because of the errors involved in the indirect measurement of body fat mass and because of differences in fat cell size between different fat depots $(20,21)$. We used the baboon to test the hypothesis that infant overfeeding leads to increased adiposity characterized by increased fat cell number. Our previous experiment (22) demonstrated that infant caloric intake did not influence fat cell number in the infant baboon at the time of weaning. In this paper we report the effects of pre-

Address correspondence to Dr. Lewis, Department of Physiology and Medicine, Southwest Foundation for Biomedical Research, P.O. Box 28147, San Antonio, TX 78284.

Received for publication 31 March 1986.

J. Clin. Invest.

(c) The American Society for Clinical Investigation, Inc.

0021-9738/86/10/0899/07 \$1.00

Volume 78, October 1986, 899-905 weaning food intake on the mass, fat cell number, and fat cell size of 10 fat depots in young adult baboons.

\section{Methods}

Experimental design. Newborn baboons (Papio cynocephalus, the progeny of six sires mated with $\mathbf{4 8}$ dams) were randomly assigned to one of three formula fed groups: underfed, normally fed, and overfed. Normally fed male and female baboons gained an amount of weight similar to that of breastfed infants $(960 \mathrm{~g}, 61 \mathrm{~g} \mathrm{SD}$ for eight male; and $987 \mathrm{~g}, 80 \mathrm{~g} \mathrm{SD}$ for five female breastfed baboons, Lewis, D. S., H. A. Bertrand, C. A. McMahan, H. C. McGill, Jr., K. D. Carey, and E. J. Masoro, unpublished observations). Each diet group consisted of 16 baboons balanced for gender. All baboons were hand-fed by bottle until 16 wk of age and weaned onto an identical diet until they were necropsied at $\sim 5 \mathrm{yr}$ of age.

Experimental diets and feeding. Infant formulas of various caloric densities were prepared by diluting 30 parts of concentrated Similac (Ross Laboratories, Columbus, $\mathrm{OH})$ with either 70 parts water $(40.5$ $\mathrm{kcal} / 100 \mathrm{~g}), 30$ parts water $(67.5 \mathrm{kcal} / 100 \mathrm{~g})$, or 12.8 parts water $(94.5$ $\mathrm{kcal} / 100 \mathrm{~g}$ ). Infants in each diet group were fed similar volumes from a bottle four times a day at $0700,1000,1300$, and 1600 hours. Food intake was measured by weighing the bottle containing formula before and after feeding.

Baboons were weaned starting at $16 \mathrm{wk}$ of age by mixing increasing amounts of solid chow with formula over 2 wk until the infant was eating solid food. All baboons were weaned onto the same diet, which was made by mixing Monkey Chow-25-5045-6 (Ralston-Purina Co., St. Louis, MO) with dried egg yolk (4.8\%), lard (14.3\%), sodium chloride (1.1\%), retinyl acetate $(0.001 \%)$, ascorbic acetate $(0.1 \%)$, and cholesterol $(0.5 \%)$. This diet contained $40 \%$ of calories as lard, $39 \%$ as carbohydrate, $21 \%$ as protein, and $1.7 \mathrm{mg}$ cholesterol/ $\mathrm{kcal}(23)$. All animals were housed indoors until $1 \mathrm{yr}$ of age and then were moved to outdoor gang cages until $5 \mathrm{yr}$ of age. The only manipulations of these animals after weaning were tests for tuberculosis semi-annually and weighing and blood sampling quarterly. 15 baboons died during the experiment and are excluded from the analyses. 3 deaths occurred during the preweaning period of life and 12 deaths occurred postweaning.

Measurement of adipocyte size and fat cell number. The adipose tissue depots excised were the same as in our previous study (22). Wet weight, triglyceride mass, fat cell volume, and fat cell number were measured as described previously (22) in the omental, mesenteric, pelvic, groin, pericardial, posterior and anterior flank, axillary, popliteal, and perirenal fat depots.

The mean diameter of adipocytes was measured by the method of Di Girolamo et al. (24) as modified by Stiles et al. (25). Briefly, adipocytes were isolated from a portion of adipose tissue by collagenase digestion and the cell diameters of the adipocytes were measured microscopically. Mean adipocyte volume was calculated assuming the freed adipocytes were spheres. In our laboratory this method yields the same results as the osmium-fixed/Coulter counter method of Hirsch and Gallian (26). Also, Lavau et al. (27) found no significant difference between the fat cell size obtained from microscopic measurement of cell diameter compared with the fat cell size determined from osmium fixed cells.

Fat cell number for each fat depot was calculated in the following manner. A portion of each fat depot was extracted for triglycerides, and triglyceride content of the extract was measured by previously described methods $(25,28)$. Fat cell number was calculated by dividing the total volume of triglyceride per depot by the mean adipocyte volume. 
Table I. Infant Energy Intake, Infant Weight Gain, Weight at Weaning and at 5 yr of age

\begin{tabular}{|c|c|c|c|c|c|}
\hline Infant diet & Gender $(n)$ & Infant energy intake & $\begin{array}{l}\text { Infant weight gain } \\
\text { (birth to } 16 \mathrm{wk} \text { ) }\end{array}$ & Weight at weaning & Weight at $5 \mathrm{yr}$ \\
\hline & & kcal & $g$ & $g$ & $k g$ \\
\hline \multirow[t]{2}{*}{$\begin{array}{l}\text { Underfed } \\
(40.5 \mathrm{kcal} / 100 \mathrm{~g})\end{array}$} & Male (4) & $\begin{array}{l}13,865^{* *} \ddagger \\
(12,731-15,099)\end{array}$ & $\begin{array}{l}193 \ddagger \\
(156-238)\end{array}$ & $\begin{array}{l}1,174 \ddagger \\
(1,077-1,280)\end{array}$ & $\begin{array}{l}20.01 \\
(17.69-22.62)\end{array}$ \\
\hline & Female (4) & $\begin{array}{l}16,055 \ddagger \\
(14,576-17,683)\end{array}$ & $\begin{array}{l}308 \ddagger \\
(243-391)\end{array}$ & $\begin{array}{l}1,247 \ddagger \\
(1,131-1,375)\end{array}$ & $\begin{array}{l}15.49 \\
(13.48-17.80)\end{array}$ \\
\hline \multirow[t]{2}{*}{$\begin{array}{l}\text { Normally fed } \\
(67.5 \mathrm{kcal} / 100 \mathrm{~g})\end{array}$} & Male (6) & $\begin{array}{l}25,278 \\
(23,704-26,958)\end{array}$ & $\begin{array}{l}956 \\
(816-1,120)\end{array}$ & $\begin{array}{l}1,949 \\
(1,826-2,080)\end{array}$ & $\begin{array}{l}19.60 \\
(17.87-21.50)\end{array}$ \\
\hline & Female (6) & $\begin{array}{l}24,220 \\
(22,488-26,086)\end{array}$ & $\begin{array}{l}861 \\
(717-1,033)\end{array}$ & $\begin{array}{l}1,732 \\
(1,607-1,867)\end{array}$ & $\begin{array}{l}13.24 \\
(11.90-14.73)\end{array}$ \\
\hline \multirow[t]{2}{*}{$\begin{array}{l}\text { Overfed } \\
(94.5 \mathrm{kcal} / 100 \mathrm{~g})\end{array}$} & Male (7) & $\begin{array}{l}32,070 \S \\
(30,184-34,073)\end{array}$ & $\begin{array}{l}1,135^{\| \prime} \\
\quad(978-1,317)\end{array}$ & $\begin{array}{l}2,145 \S \\
(2,017-2,281)\end{array}$ & $\begin{array}{l}20.21 \\
(18.53-22.06)\end{array}$ \\
\hline & Female (5) & $\begin{array}{l}33,009 \S \\
(30,571-35,642)\end{array}$ & $\begin{array}{l}1,251 \S \\
(1,035-1,510)\end{array}$ & $\begin{array}{l}2,166 \S \\
(2,005-2,341)\end{array}$ & $\begin{array}{l}18.42 \S \\
(16.50-20.57)\end{array}$ \\
\hline
\end{tabular}

* Mean $(95 \%$ confidence intervals). $¥$ Significant difference between underfed and normally fed $(P<0.05)$. $\S$ Significant difference between overfed and both underfed and normally fed $(P<0.05)$. "Significant difference between overfed and underfed $(P<0.05)$.

Statistical methods. The data were evaluated by analysis of variance (29). Before this analysis, the data were transformed with a natural logarithm transformation to better satisfy the assumptions of normality and homogeneity of variance. The linear model included terms for the overall mean, the main effects of diet, sex, and sire, and the two-factor interactions diet by sex and sex by sire. The parameters of the linear model were estimated by a robust $\mathrm{M}$-estimator (30) and tests of hypotheses were made by a robust likelihood ratio type test (31). The M-estimate gives less weight to outliers in the data than classical methods do. When infant diet significantly $(P<0.05)$ affected a variable, pairwise comparisons of overfeeding, normal feeding, and underfeeding were made.

\section{Results}

Effect of infant formula on caloric intake and subsequent growth. The infant caloric intakes and subsequent weight gains of underfed, normally fed, and overfed baboons are reported in Table I. During formula feeding the underfed baboons received $\sim 40 \%$ fewer calories than normally fed baboons, and the overfed baboons received $\sim 31 \%$ more calories than normally fed baboons. Underfed female baboons consumed more calories $(P<0.03)$ than underfed males, but there were no differences in caloric intake between males and females that were fed normally or overfed. Underfed male and female baboons gained 80 and $64 \%$ less weight $(P<0.0001)$, respectively, than normally fed infants during the period of formula feeding. Overfed female infants gained $45 \%$ more weight $(P<0.0001)$ during formula feeding than normally fed female baboons. The mean weight gain of the overfed male infants was $19 \%$ more than normally fed males $(P$ $<0.07$ ).

Both overfed male and female baboons weighed more at weaning than normally fed baboons, while underfed male and female baboons weighed less than normally fed baboons. At 5 yr of age, only females overfed as infants weighed more $(P<0.05)$ than either normally fed or underfed infants. At 5 yr there were no differences in body weight among males. The body mass of these baboons from 16 wk to $5 \mathrm{yr}$ of age are shown in Fig. 1, and the weight gains during postweaning infancy (16-48 wk), the juvenile period (48-169 wk), and adolescence (169-252 wk) are reported in Table II. By 1 yr of age, the body weights of the three groups of female and male baboons were similar (Fig. 1) and there was no difference in weight gain among baboons overfed, fed normally, or underfed. Beginning at 48 wk of age female baboons, overfed as infants, increased body weight at a greater rate $(P<0.02)$ than normally fed infants, such that by $5 \mathrm{yr}$ of age they were $29 \%$ heavier than the baboons that were fed normally. Although females overfed as infants gained more weight during the juvenile and adolescent periods than did females underfed as infants, the difference was not statistically significant. There was no significant effect of infant food intake on male body weight or rate of weight gain from 1 to $5 \mathrm{yr}$ of age. Underfed baboons gained, on the average, more mass during each period than normally fed infants, but these differences were not statistically significant.

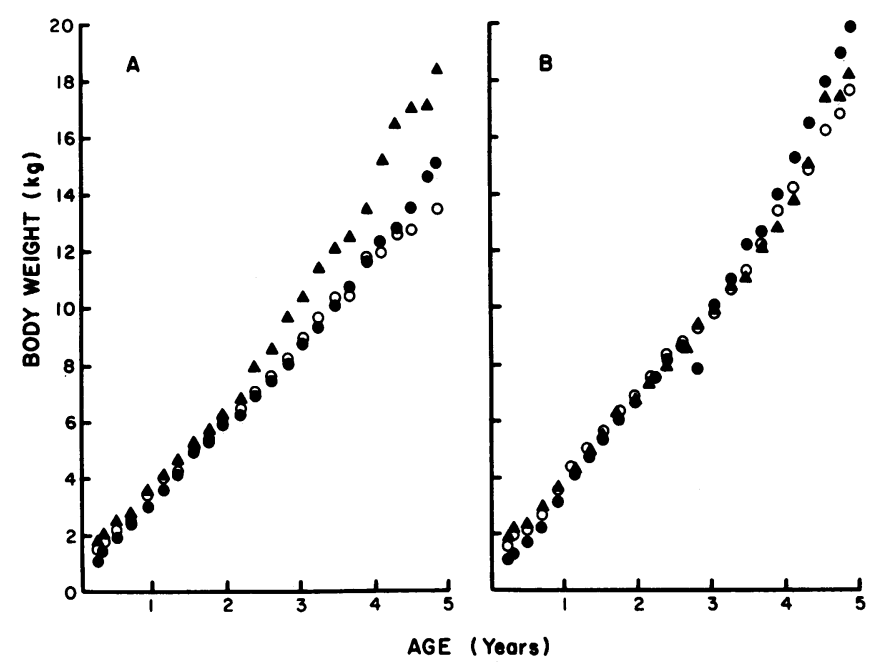

Figure 1. Weight of baboons from birth to $5 \mathrm{yr}$ of age. Points represent mean weights for each diet group at each indicated age. (0) Represent baboons fed $67.5 \mathrm{kcal} / 100 \mathrm{~g}$ formula as infants; (๑) represent baboons fed $40.5 \mathrm{kcal} / 100 \mathrm{~g}$ formula as infants; and $(\Lambda)$ represent baboons fed $94.5 \mathrm{kcal} / 100 \mathrm{~g}$ formula as infants. $(A)$ Female baboons; $(B)$ male baboons. 
Table II. Weight Gain ( $k g$ ) of Underfed, Normally Fed, and Overfed Infants during Postweaning (16-48 wk), Juvenile (48-169wk), and Adolescent (169-252 wk) Periods

\begin{tabular}{lllll}
\hline \multirow{2}{*}{ Infant diet } & Gender $(n)$ & $16-48 \mathrm{wk}$ & $48-169 \mathrm{wk}$ & $169-252 \mathrm{wk}$ \\
\cline { 3 - 5 } Underfed & Male (4) & $1.9(1.4-2.5)^{*}$ & $7.3(6.2-8.3)$ & $9.0(7.5-10.6)$ \\
& Female (4) & $1.9(1.3-2.5)$ & $6.3(5.2-7.5)$ & $6.1(4.3-7.8)$ \\
Normally fed & Male (6) & $1.6(1.2-2.0)$ & $7.0(6.2-7.8)$ & $7.3(6.1-8.5)$ \\
& Female (6) & $1.7(1.3-2.2)$ & $5.8(4.9-6.7)$ & $4.0(2.6-5.3)$ \\
Overfed & Male (7) & $1.6(1.2-2.0)$ & $6.9(6.2-7.6)$ & $7.8(6.7-8.9)$ \\
& Female (5) & $1.7(1.2-2.2)$ & $7.5(6.6-8.4)$ & $7.0(5.6-8.4)$
\end{tabular}

* Mean ( $95 \%$ confidence interval).

From 169 to 252 wk, males, fed normally and underfed as infants, gained more weight $(P<0.002)$ than similarly treated females. There were no significant differences in weight gain between males and females that were overfed as infants.

One female baboon, overfed as an infant, lost $3 \mathrm{~kg}$ of body weight during the last 9 mo of the experiment and weighed 13.05 $\mathrm{kg}$ at $5 \mathrm{yr}$ of age (compared with $18.42 \mathrm{~kg}$ mean weight for the entire overfed group). During our experiment no other animal lost weight over a period of $>3 \mathrm{mo}$. However, since no evidence of disease was apparent at necropsy other than prior weight loss, this animal has been included in the data analysis. Indeed, an appreciable part of the variability seen in the overfed females is due to this animal.

Effect of infant food intake on adipose tissue mass. The masses of 10 fat depots in 5-yr-old baboons are reported in Tables III and IV. Female baboons overfed as infants had markedly greater triglyceride mass in all fat depots than the female baboons that were either fed normally or underfed as infants. There was a significant difference between female baboons that were fed normally and those underfed as infants in only the anterior flank

Table III. Fat Depot Triglyceride

Mass (g) in Adult Female Baboons

\begin{tabular}{llll}
\hline & Infant diet & & \\
\cline { 2 - 4 } Depot & $\begin{array}{l}\text { Underfed } \\
(n=4)\end{array}$ & $\begin{array}{l}\text { Normally fed } \\
(n=6)\end{array}$ & $\begin{array}{l}\text { Overfed } \\
(n=5)\end{array}$ \\
\hline Omentum & $35.4(16.8-74.7)^{*}$ & $53.4(30.1-94.8)$ & $202.7(112.0-366.7) \ddagger$ \\
Pericardial & $6.7(2.6-17.3)$ & $6.1(3.0-12.7)$ & $33.6(15.8-71.6) \ddagger$ \\
Perirenal & $42.7(16.5-110.6)$ & $37.3(18.0-77.4)$ & $253.8(119.2-540.2) \ddagger$ \\
Pelvic & $15.7(6.2-39.9)$ & $13.7(7.1-26.3)$ & $44.2(22.5-86.5) \ddagger$ \\
Axillary & $8.8(3.7-20.7)$ & $16.3(8.4-31.4)$ & $103.6(52.4-204.7) \ddagger$ \\
Popliteal & $10.4(5.3-20.7)$ & $12.1(7.2-20.5)$ & $34.0(19.8-58.5) \ddagger$ \\
Anterior & & & $26.1(11.6-58.5) \ddagger$ \\
$\quad$ flank & $1.1(0.4-3.1)$ & $6.7(3.1-14.6) \S$ & $29.2(11.5-74.1) \ddagger$ \\
Posterior & & & $29.6(12.5-69.8) \ddagger$ \\
$\quad$ flank & $1.2(0.3-5.0)$ & $3.4(1.3-8.5)$ & $258.9(124.7-537.5) \ddagger$ \\
Groin & $3.4(1.2-10.0)$ & $5.4(2.4-12.4)$ & \\
Mesentery & $22.7(9.0-56.8)$ & $58.6(28.9-118.7)$ & \\
& & &
\end{tabular}

* Mean (95\% confidence intervals).

¥ Significant difference between overfed and both normally fed and underfed $(P<0.05)$.

$\S$ Significant difference between normally fed and underfed $(P<0.05)$.
Table IV. Fat Depot Triglyceride Mass (g) in Adult Male Baboons

\begin{tabular}{|c|c|c|c|}
\hline \multirow[b]{2}{*}{ Depot } & \multicolumn{3}{|l|}{ Infant diet } \\
\hline & $\begin{array}{l}\text { Underfed } \\
(n=4)\end{array}$ & $\begin{array}{l}\text { Normally fed } \\
(n=6)\end{array}$ & $\begin{array}{l}\text { Overfed } \\
(n=7)\end{array}$ \\
\hline Omentum & $29.3(15.2-56.7)^{*}$ & $24.8(15.1-40.8)$ & $60.0(37.6-95.9) \ddagger$ \\
\hline Pericardial & $3.4(1.5-7.8)$ & $3.6(1.9-6.8)$ & $8.0(4.4-14.6)$ \\
\hline Perirenal & $16.6(7.2-38.4)$ & $17.4(9.3-32.8)$ & $50.0(27.6-90.9)$ \\
\hline Pelvic & $11.3(5.3-23.8)$ & $9.0(5.1-15.8)$ & $16.7(9.8-28.4)$ \\
\hline Axillary & $7.0(3.3-14.9)$ & $6.4(3.6-11.4)$ & $15.7(9.1-26.8)$ \\
\hline Popliteal & $9.2(5.0-16.9)$ & $9.7(6.1-15.2)$ & $14.4(9.4-22.2)$ \\
\hline \multicolumn{3}{|l|}{ Anterior } & $3.8(1.9-7.4) \S$ \\
\hline \multicolumn{4}{|l|}{ Posterior } \\
\hline flank & $0.7(0.2-1.8)$ & $0.6(0.3-1.4)$ & $4.0(1.8-8.7) \S$ \\
\hline Groin & $2.2(0.9-5.8)$ & $2.6(1.3-5.4)$ & $5.4(2.7-10.7)$ \\
\hline Mesentery & $12.0(5.3-27.0)$ & $14.3(7.7-26.4)$ & $71.3(38.6-131.9) \S$ \\
\hline
\end{tabular}

* Mean (95\% confidence intervals)

‡ Significant difference between overfed and normally fed $(P<0.05)$.

$\S$ Significant difference between overfed and both normally fed and underfed $(P<0.05)$.

depot. 5-yr-old males, overfed as infants, had a greater triglyceride mass in 4 of 10 fat depots than baboons fed normally or underfed as infants, but the difference was smaller than that observed with females. There were no significant differences in depot triglyceride mass between male baboons fed normally or underfed as infants.

Effect of infant food intake on adipocyte size. The mean adipocyte volumes of the 10 fat depots from 5-yr-old baboons that were underfed, fed normally, or overfed during infancy are reported in Tables V and VI. Fat cells from each fat depot showed marked hypertrophy in overfed females (Table V) compared with both normally fed and underfed females. Although the normally fed female baboons had a larger mean fat cell volume than did underfed female baboons, this increase in cell size was not statistically significant.

Table V. Adipocyte Volume (nl) in Adult Female Baboons

\begin{tabular}{|c|c|c|c|}
\hline \multirow[b]{2}{*}{ Depot } & \multicolumn{3}{|l|}{ Infant diet } \\
\hline & $\begin{array}{l}\text { Underfed } \\
(n=4)\end{array}$ & $\begin{array}{l}\text { Normally fed } \\
(n=6)\end{array}$ & $\begin{array}{l}\text { Overfed } \\
(n=5)\end{array}$ \\
\hline Omentum & $0.140(0.057-0.346)^{*}$ & $0.356(0.178-0.712)$ & $0.965(0.471-1.977) \ddagger$ \\
\hline Pericardial & $0.163(0.077-0.344)$ & $0.297(0.167-0.527)$ & $0.724(0.399-1.311) \ddagger$ \\
\hline Perirenal & $0.176(0.083-0.371)$ & $0.286(0.161-0.508)$ & $1.074(0.592-1.947) \ddagger$ \\
\hline Pelvic & $0.251(0.137-0.460)$ & $0.306(0.192-0.487)$ & $0.799(0.494-1.291) \ddagger$ \\
\hline Axillary & $0.113(0.068-0.190)$ & $0.139(0.094-0.207)$ & $0.466(0.309-0.703) \ddagger$ \\
\hline Popliteal & $0.164(0.108-0.247)$ & $0.192(0.140-0.264)$ & $0.346(0.249-0.480) \ddagger$ \\
\hline \multicolumn{4}{|l|}{ Anterior } \\
\hline flank & $0.205(0.101-0.414)$ & $0.304(0.177-0.522)$ & $0.816(0.466-1.427) \ddagger$ \\
\hline \multicolumn{4}{|l|}{ Posterior } \\
\hline flank & $0.130(0.056-0.305)$ & $0.247(0.141-0.433)$ & $0.709(0.405-1.242) \ddagger$ \\
\hline Groin & $0.198(0.104-0.374)$ & $0.260(0.160-0.425)$ & $0.794(0.478-1.317) \ddagger$ \\
\hline Mesentery & $0.182(0.074-0.450)$ & $0.340(0.170-0.681)$ & $1.165(0.568-2.389) \ddagger$ \\
\hline
\end{tabular}

* Mean ( $95 \%$ confidence interval).

¥ Significant difference between overfed and both normally fed and underfed $(P<0.05)$. 
Table VI. Adipocyte Volume (nl) in Adult Male Baboons

\begin{tabular}{|c|c|c|c|}
\hline \multirow[b]{2}{*}{ Depot } & \multicolumn{3}{|l|}{ Infant diet } \\
\hline & $\begin{array}{l}\text { Underfed } \\
(n=4)\end{array}$ & $\begin{array}{l}\text { Normally fed } \\
(n=6)\end{array}$ & $\begin{array}{l}\text { Overfed } \\
(n=7)\end{array}$ \\
\hline Omentum & $0.099(0.045-0.220)^{*}$ & $0.106(0.058-0.193)$ & $0.217(0.123-0.382)$ \\
\hline Pericardial & $0.107(0.055-0.208)$ & $0.094(0.057-0.155)$ & $0.232(0.145-0.371)$ \\
\hline Perirenal & $0.117(0.060-0.227)$ & $0.114(0.069-0.188)$ & $0.250(0.156-0.400)$ \\
\hline Pelvic & $0.172(0.101-0.293)$ & $0.166(0.111-0.248)$ & $0.267(0.183-0.390)$ \\
\hline Axillary & $0.082(0.052-0.130)$ & $0.075(0.053-0.106)$ & $0.131(0.095-0.181) \ddagger$ \\
\hline Popliteal & $0.132(0.092-0.190)$ & $0.127(0.096-0.167)$ & $0.183(0.141-0.238)$ \\
\hline \multicolumn{4}{|l|}{ Anterior } \\
\hline flank & $0.128(0.069-0.239)$ & $0.128(0.080-0.204)$ & $0.256(0.164-0.398)$ \\
\hline \multicolumn{4}{|l|}{ Posterior } \\
\hline flank & $0.103(0.055-0.192)$ & $0.114(0.072-0.183)$ & $0.194(0.125-0.301)$ \\
\hline Groin & $0.127(0.073-0.224)$ & $0.140(0.092-0.214)$ & $0.248(0.166-0.370)$ \\
\hline Mesentery & $0.107(0.048-0.238)$ & $0.103(0.057-0.189)$ & $0.233(0.132-0.412)$ \\
\hline
\end{tabular}

* Mean (95\% confidence interval).

¥ Significant difference between overfed and normally fed and underfed ( $P$ $<0.05)$.

In contrast to female baboons, overfed male baboons (Table VI) had only marginal increases in fat cell size, with significantly larger fat cells in only one depot. Although the omental, mesenteric, and flank depots had significantly more mass in overfed males compared with normally fed and underfed males, infant caloric intake did not have a significant effect on fat cell size ( $P$ $<0.1,0.07,0.15$, and 0.14 , respectively). There were no differences in fat cell size between males who had been fed normally and those who had been underfed.

Effect of infant food intake on adipocyte cell number. Fat cell numbers for each fat depot from adult baboons underfed, fed normally, and overfed as infants are reported in Tables VII and VIII. In adult female baboons, infant food intake influenced fat cell number in only four depots. Infant overfeeding compared with both normal and underfeeding led to small but significant

Table VII. Fat Cell Number $\left(\times 10^{7}\right)$ in Adult Female Baboons

\begin{tabular}{|c|c|c|c|}
\hline \multirow[b]{2}{*}{ Depot } & \multicolumn{3}{|l|}{ Infant diet } \\
\hline & $\begin{array}{l}\text { Underfed } \\
(n=4)\end{array}$ & $\begin{array}{l}\text { Normally fed } \\
(n=6)\end{array}$ & $\begin{array}{l}\text { Overfed } \\
(n=5)\end{array}$ \\
\hline Omentum & $28.1(19.6-40.4)^{*}$ & $16.5(12.5-21.8)$ & $23.2(17.4-31.0)$ \\
\hline Pericardial & $4.4(2.8-6.9)$ & $2.3(1.6-3.2) \ddagger$ & $5.1(3.6-7.3)$ \\
\hline Perirenal & $26.9(15.9-45.5)$ & $14.5(9.7-21.7)$ & $26.1(17.2-39.6)$ \\
\hline Pelvic & $6.5(3.2-13.3)$ & $5.0(3.0-8.2)$ & $6.1(3.7-10.2)$ \\
\hline Axillary & $8.1(3.8-17.5)$ & $12.7(7.0-22.9)$ & $22.3(12.1-41.0)$ \\
\hline Popliteal & $7.1(4.3-11.6)$ & $7.0(4.8-10.2)$ & $10.9(7.3-16.1)$ \\
\hline \multicolumn{4}{|l|}{ Anterior } \\
\hline flank & $0.8(0.5-1.3)$ & $2.4(1.7-3.4) \S$ & $3.6(2.5-5.1)^{\prime \prime}$ \\
\hline \multicolumn{4}{|l|}{ Posterior } \\
\hline flank & $1.3(0.6-2.6)$ & $1.5(1.0-2.3)$ & $4.6(3.0-6.9) \pi$ \\
\hline Groin & $2.8(1.7-4.5)$ & $2.2(1.6-3.0)$ & $4.4(3.1-6.2)^{* *}$ \\
\hline Mesenteric & $13.7(9.2-20.5)$ & $18.9(13.9-25.8)$ & $24.5(17.8-33.7)$ \\
\hline
\end{tabular}

* Mean (95\% confidence interval).

‡ Significant difference between normally fed and both underfed and overfed $(P<0.05)$.

§ Significant difference between normally fed and underfed $(P<0.05)$.

"Significant difference between overfed and underfed $(P<0.05)$.

I Significant difference between overfed and both underfed and normally fed $(P<0.05)$.

* Significant difference between overfed and normally fed $(P<0.05)$.
Table VIII. Fat Cell Number $\left(\times 10^{7}\right)$ in Adult Male Baboons

\begin{tabular}{llll}
\hline & Infant diet & & \\
\cline { 2 - 4 } Depot & $\begin{array}{l}\text { Underfed } \\
(n=4)\end{array}$ & $\begin{array}{l}\text { Normally fed } \\
(n=6)\end{array}$ & $\begin{array}{l}\text { Overfed } \\
(n=7)\end{array}$ \\
\hline Omentum & $32.8(23.8-45.3)^{*}$ & $26.1(20.5-33.2)$ & $29.7(23.7-37.3)$ \\
Pericardial & $3.4(2.3-5.0)$ & $4.2(3.1-5.6)$ & $4.2(3.2-5.6)$ \\
Perirenal & $16.0(10.1-25.4)$ & $17.5(12.3-24.8)$ & $19.4(14.0-27.0)$ \\
Pelvic & $7.3(4.2-13.0)$ & $5.9(3.9-9.1)$ & $6.9(4.6-10.4)$ \\
Axillary & $9.4(4.8-18.6)$ & $9.6(5.7-16.0)$ & $12.6(7.8-20.4)$ \\
Popliteal & $7.7(5.0-11.9)$ & $8.4(6.1-11.7)$ & $8.6(6.3-11.8)$ \\
Anterior & & & $1.5(1.1-2.0)$ \\
$\quad$ flank & $1.1(0.7-1.6)$ & $0.9(0.6-1.2)$ & \\
Posterior & & & $2.0(1.4-2.8) \ddagger$ \\
$\quad$ flank & $0.7(0.5-1.2)$ & $0.7(0.5-0.9)$ & $2.5(1.9-3.2)$ \\
Groin & $1.9(1.3-2.8)$ & $2.1(1.5-2.7)$ & $24.6(18.8-32.2) \ddagger$ \\
Mesenteric & $13.1(9.2-18.7)$ & $16.4(12.5-21.5)$ &
\end{tabular}

* Mean (95\% confidence interval).

‡ Significant difference between overfed and both normally fed and underfed $(P<0.05)$.

increases in fat cell number in three depots, the posterior and anterior flanks and the groin. The numbers of fat cells were significantly lower in one depot (pericardial) of normally fed baboons compared with overfed and underfed female baboons. In male baboons, infant caloric intake significantly influenced fat cell number in two depots. Infant overfeeding increased the fat cell number in the posterior flank and mesenteric depots of male baboons compared with either normally fed and underfed males.

Effect of gender on fat mass distribution and adipose tissue cellularity. Table IX summarizes the significant differences $(P$ $<0.05$ ) in fat mass, fat cell volume, and fat cell number in 10 fat depots of adult male and female baboons in each diet group. In each depot, overfed female baboons had more triglyceride mass $(P<0.02)$ than similarly fed males despite the larger body mass of males. Normally fed females had more triglyceride than normally fed males $(P<0.05)$ in 5 of 10 depots (the omentum, axillary, anterior and posterior flanks, and the mesentery). Underfed male and female baboons had similar depot triglyceride mass. Among normally fed and overfed baboons, females had larger $(P<0.05)$ fat cells in every depot than did males. However, when males and females with similar depot mass were compared, there was no significant difference in fat cell size in any fat depot.

There were few consistent effects of gender on fat cell number. Normally fed female baboons had fewer fat cells in the omentum and pericardial depots but more fat cells in the posterior and anterior flank depots than normally fed male baboons. Overfed females had more fat cells than overfed males in the posterior and anterior flank and groin depots. As with fat cell size, there were no significant differences in fat cell numbers in any depot from male and female baboons that had similar fat depot masses. The relative distribution of fat mass among the 10 fat depots is reported in Table X. Male baboons had more depot fat in the omentum and popliteal depots than females, whereas female baboons had a greater portion of fat in the perirenal and posterior flank depots than males.

The effect of infant diet on the distribution of adipose mass among the 10 fat depots was small (results not shown). Only the mesenteric and posterior flank increased in relative amount of 
Table IX. Ratio of Female to Male Fat Depots Significantly Different from $1.0(P<0.05)$

\begin{tabular}{|c|c|c|c|c|c|c|c|c|c|}
\hline \multirow[b]{3}{*}{ Depot } & \multirow{2}{*}{\multicolumn{3}{|c|}{ Fat mass }} & \multicolumn{3}{|l|}{ Infant diet } & \multirow{2}{*}{\multicolumn{3}{|c|}{ Fat cell number }} \\
\hline & & & & \multicolumn{3}{|c|}{ Fat cell size } & & & \\
\hline & Underfed & Normally fed & Overfed & Underfed & Normally fed & Overfed & Underfed & Normally fed & Overfed \\
\hline \multicolumn{10}{|l|}{ Intraabdominal } \\
\hline Mesentery & * & 4.1 & 3.6 & * & 3.3 & 5.0 & * & * & * \\
\hline Omentum & * & 2.2 & 3.4 & * & 3.4 & 4.5 & * & 0.6 & * \\
\hline Perirenal & $*$ & $*$ & 5.1 & * & 2.5 & 4.3 & * & * & * \\
\hline Pelvic & * & $*$ & 2.6 & * & 1.8 & 3.0 & * & * & $*$ \\
\hline \multicolumn{10}{|l|}{ Subcutaneous } \\
\hline Posterior flank & $*$ & 5.2 & 7.4 & * & 2.2 & 3.7 & * & 2.3 & 2.3 \\
\hline Anterior flank & $*$ & 6.9 & 6.9 & $*$ & 2.4 & 3.2 & $*$ & 2.7 & 2.4 \\
\hline Groin & * & * & 5.5 & * & 1.9 & 3.2 & * & * & 1.8 \\
\hline Popliteal & * & $*$ & 2.4 & $*$ & 1.5 & 1.9 & $*$ & * & $*$ \\
\hline Axillary & * & 2.5 & 6.6 & * & 1.9 & 3.6 & * & $*$ & $*$ \\
\hline \multicolumn{10}{|l|}{ Other } \\
\hline Pericardial & $*$ & * & 4.2 & $*$ & 3.1 & 3.1 & * & 0.5 & $*$ \\
\hline
\end{tabular}

* Value not significantly different from 1.0.

fat mass. Females underfed as infants contained only $12.8 \%$ of the total fat depot mass in the mesentery depot compared with 25.6 and $24.6 \%$ for the normally fed and overfed females, respectively. Similarly, male baboons overfed as infants had $23.3 \%$ of total depot fat located in the mesentery and only 13.1 and $15.9 \%$ in the mesenteric depot of normally fed and underfed baboons.

Effect of fat cell volume on fat cell number. The relationship between mean fat cell volume and fat cell number was examined in three intraabdominal fat depots of individual baboons (Fig. 2). Fat cell number was not related to fat cell volume in the omentum, perirenal, and mesenteric depots. There was no evidence for a bimodal distribution of fat cell volume in these depots, including those depots with mean fat cell volumes exceeding $1.0 \mathrm{nl}$.

Table X. Percent of Total Depot Fat Mass in 10 Fat Depots of Male and Female Baboons at 5 yr of Age

\begin{tabular}{lcc}
\hline Fat depot & Male & Female \\
\hline Intraabdominal & & \\
Omentum & $27.2(23.4-31.6)^{*}$ & $20.6(16.6-25.4) \ddagger$ \\
Mesentery & $16.9(14.4-19.9)$ & $20.1(15.9-25.3)$ \\
Pelvic & $9.2(7.1-11.9)$ & $6.2(4.3-8.9)$ \\
Perirenal & $18.7(16.7-21.0)$ & $23.3(19.8-27.5) \ddagger$ \\
Subcutaneous & & \\
Anterior flank & $1.2(0.9-1.6)$ & $1.9(1.3-2.7)$ \\
Posterior flank & $0.9(0.7-1.1)$ & $1.6(1.2-2.3) \ddagger$ \\
Groin & $2.5(2.0-3.1)$ & $2.7(2.0-3.8)$ \\
Axillary & $6.8(5.6-8.3)$ & $8.7(6.5-11.6)$ \\
Popliteal & $8.4(6.9-10.4)$ & $5.0(3.8-6.7) \ddagger$ \\
Other & & \\
Pericardial & $3.5(3.0-4.1)$ & $3.7(3.0-4.6)$ \\
\hline
\end{tabular}

* Mean (95\% confidence intervals).

¥ Females significantly different from males $(P<0.05)$.

\section{Discussion}

Our results provide direct evidence that overnutrition during infancy increases fat depot mass later in life. Baboon infants consuming a concentrated infant formula that provided $33 \%$ more energy and other nutrients than infants fed a regular formula, or $116 \%$ more than those fed a diluted infant formula, developed a significantly greater fat depot mass by 5 yr of age. Moreover, the effect of increased preweaning food intake on fat depot mass at 5 yr of age was greater in adult females, in which all depots were affected, whereas in male baboons only 4 of 10 depots were affected. These results are consistent with previous

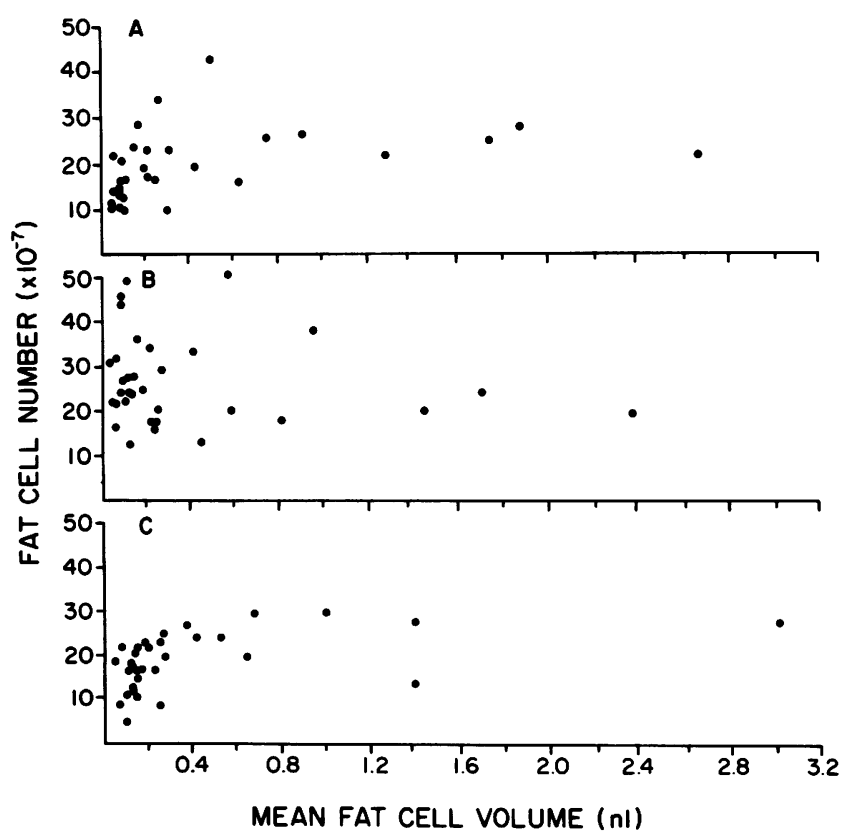

Figure 2. Relationship between fat cell size and fat cell number in mesenteric $(A)$, omental $(B)$, and perirenal $(C)$ fat depots. 
findings in rats that adult fat mass is increased when preweaning food intake is increased by reducing the number of pups per litter $(16,17)$ or by formula supplementation of the pups $(32)$.

Increased fat cell number has been proposed $(10,11,15,33)$ to be the major mechanism by which infant overfeeding leads to an increased fat depot mass in the adult. This hypothesis is not supported by our findings with the baboon. Rather, the marked enlargement of the fat cells accounts for most of the increased triglyceride mass in fat depots of baboons overfed as infants.

Whether the fat cell number hypothesis applies to humans is controversial $(20,21,34)$. The adequacy of the employed methods are at the base of this controversy. The validity of indirect methods used to estimate total body fat in humans and the small amount of adipose tissue sampled from limited anatomical sites compromise the accuracy of fat cell number estimates for humans (20). Data both supporting and contradicting the fat cell hypothesis are based on these questionable methods $(9-15,21,34)$. In our experiments with the baboon, these methodological difficulties have largely been circumvented. Fat mass and the mean fat cell size were measured directly in 10 widely distributed fat depots.

Why excessive preweaning food intake increases fat depot mass primarily by fat cell hypertrophy in the adult baboon, while it increases fat depot mass primarily by fat cell hyperplasia in the adult rat, is not apparent. The degree of maturity at birth may be an important factor. Rats are much less mature (altricial) than primates during preweaning life and, in a sense, neonatal rats may be similar to a late gestational fetal primate. Fat depots begin to form during late gestation in primates, and it has been hypothesized that fat cell number is sensitive to overnourishment in utero $(15,33)$. Indeed, the few depots in which cell hyperplasia did occur in the baboons overfed as infants are either not present (groin, flank depots) or poorly developed (mesenteric) at birth (Lewis, D. S., unpublished observations). Also, the fat cells of baboons become larger than those reported for rats (35). This capacity may make the baboon resistant to fat cell hyperplasia. Proliferation of fat cells has been hypothesized to occur in rats after fat cell size increases to a critical level $(18,35,36)$. Faust et al. (18) have suggested that the critical cell size for triggering fat cell hyperplasia in adult rats is $1.2-1.6 \mu \mathrm{g}(\sim 1.3-1.75 \mathrm{nl})$. However, in the fat depots of baboons with mean fat cell sizes $>1.75 \mathrm{nl}$ there was no evidence for fat cell hyperplasia. Of course, with increasing time the depots with very large fat cells may increase fat cell number, but the data of our study do not indicate that this will occur. Another possible reason why fat cell hyperplasia was not observed in baboons could be because of their genetic diversity. Johnson et al. (17) have reported that genotype was the single most important factor in determining fat cell numbers in rats. Zucker-obese rats, when overfed as pups, had a greater increase in fat cell number than did Zucker-lean rats overfed as pups. It should be possible to test possible genetic influences on the response to infant overfeeding in pedigreed baboons.

The mechanism by which a dietary manipulation such as formula overfeeding during the first $16 \mathrm{wk}$ of life influences fat depot mass 5 yr later is unknown. The large weight gain (and thus, by inference, gain in fat mass) in female baboons overfed as infants may have been due to increased food intake and decreased activity. These were not measured in this study.

It is also not evident why there is less increase in fat mass at $5 \mathrm{yr}$ of age in males that were overfed as infants than in similarly treated females. Differences in weight due to infant formula intake largely disappeared by 1 yr of age in both males and females. The body weight of male baboons from all three dietary regimens were similar throughout the rest of the experiment. The increase in body weight beginning at $169 \mathrm{wk}$ of age in the female baboons overfed as infants suggests that the effect of infant feeding on fat mass is deferred to puberty, when normal growth requires fat deposition. Indeed, most of the weight difference between females that were overfed and fed normally as infants was gained between 3 and 5 yr of age. Baboons enter puberty $\sim 3$ yr of age (37) and it appears from our findings that female baboons develop more fat mass than males during puberty, as in humans (38). Infant overfeeding may have had no effect on adiposity in male baboons because, during the pubertal growth spurt, which occurred around 5 yr of age in male baboons (38), increased androgen levels in the male may have promoted lean tissue development and decreased the energy available for adipose tissue deposition.

In the present study there is no clear evidence for either a android or a gynoid fat distribution in baboons. Although female baboons that were fed normally and overfed as infants had considerably more absolute fat mass and larger fat cells than similarly fed male baboons, the distribution of mass among the 10 depots analyzed was remarkedly similar between males and females. Further, there were no significant differences in fat cell volume, fat cell number, and distribution of fat mass in male and female baboons with similar fat depot masses (underfed males and females and overfed males and normally fed females). In contrast to the baboon, differences in fat distribution among subcutaneous fat depots in 260 men and 670 women have been reported by Krotkiewski et al. (39). It is difficult to compare our results with those from humans because we did not assess abdominal subcutaneous fat and because the number of baboons was small. It is clear, however, that the increased adiposity in both male and female baboons due to infant overfeeding is primarily of the hypertrophic type, and that the largest fat cells and most of the fat depot mass are located in the abdominal fat depots. It is this type of fat pattern that is associated with the metabolic aberrations in obesity (40-43).

In conclusion, preweaning food intake in the baboon does influence fat mass $5 \mathrm{yr}$ later. The female is influenced more than the male. Differences in fat cell number are not a major reason for this effect. Thus, the fat cell number hypothesis for primates is not supported by the present study. Rather, preweaning nutrition influences adult adiposity by some other mechanism that caused marked hypertrophy of existing fat cells.

\section{Acknowledgments}

The authors gratefully acknowledge the assistance of Ronnie Braendle, Jimmy Burd, Cornelio Celaya, Mary Lou Estrello, Terry Hawkins, Judy Odom, Cynthia Stacy, Janet Straus, Elaine Windhorst, and Ned Zamora.

This work was supported in part by National Heart, Lung and Blood Institute grants HL-19362 and HL-28728.

\section{References}

1. A disease in many guises. 1985. Science (Wash. DC). 230:1019.

2. Whitelaw, A. 1977. Infant feeding and subcutaneous fat at birth and at one year. Lancet. ii:1098-1099.

3. Eid, E. E. 1970. Follow-up study of physical growth of children who had excessive weight gain in first six months of life. Br. Med. J. 2: 74-76. 
4. Häger, A., L. Sjöstorm, B. Arvidsson, P. Björntorp, and U. Smith. 1977. Body fat and adipose tissue cellularity in infants: a longitudinal study. Metab. Clin. Exp. 26:607-614.

5. Charney, E., H. C. Goodman, M. McBride, B. Lyon, and R. Pratt. 1976. Childhood antecedents of adult obesity. Do chubby infants become obese adults? N. Engl. J. Med. 295:6-9.

6. Durnin, J. V. G. A., and F. M. McKillop. 1978. The relationship between body build in infancy and percentage body fat in adolescence: a 14 year follow-up on 102 infants. Proc. Nutr. Soc. 37:81A. (Abstr.)

7. Miller, F. J. W., W. Z. Billewicz, and A. M. Thomson. 1972. Growth from birth to adult life of $\mathbf{4 4 2}$ Newcastle-upon-Tyne children. Br. J. Prev. Soc. Med. 26:224-230.

8. Shapiro, L. R., P. B. Crawford, M. J. Clark, D. L. Pearson, J. Raz, and R. L. Huenemann. 1984. Obesity prognosis: a longitudinal study of children from the age of 6 months to 9 years. Am. J. Public Health. 74: 968-972.

9. Hirsch, J. 1975. Cell number and size as a determinant of subsequent obesity. In Childhood Obesity. M. Winick, editor. John Wiley \& Sons, New York. 15-21.

10. Hirsch, J., and J. L. Knittle. 1970. Cellularity of obese and nonobese human adipose tissue. Fed. Proc. 29:1516-1521.

11. Bray, G. A. 1970. Measurement of subcutaneous fat cells from obese patients. Ann. Intern. Med. 73:565-569.

12. Salans, L. B., S. W. Cushman, and R. E. Weismann. 1973. Studies of human adipose tissue. Adipose cell size and number in nonobese and obese patients. J. Clin. Invest. 52:929-941.

13. Sjöstrom, L., and P. Björntorp. 1974. Body composition and adipose tissue cellularity in human obesity. Acta Med. Scand. 195:201211.

14. Knittle, J. L. 1972. Obesity in childhood: a problem in adipose tissue cellular development. J. Pediatr. 81:1048-1059.

15. Brook, C. G. D., J. K. Lloyd, and O. H. Wolf. 1972. Relation between age of onset of obesity and size and number of adipose cells. Br. Med. J. 2:25-27.

16. Knittle, J. L., and J. Hirsch. 1968. Effect of early nutrition on the development of rat epididymal fat pads. Cellularity and metabolism. J. Clin. Invest. 47:2091-2098.

17. Johnson, P. R., J. S. Stern, M. R. C. Greenwood, L. M. Zucker, and J. Hirsch. 1973. Effect of early nutrition on adipose cellularity and pancreatic insulin release in the Zucker rat. J. Nutr. 103:738-743.

18. Faust, I. M., P. R. Johnson, J. S. Stern, and J. Hirsch. 1978. Diet-induced adipocyte number increase in adult rats: A new model of obesity. Am. J. Physiol. 235:E279-E286.

19. Lemmonier, D. 1972. Effect of age, sex, and site on the cellularity of adipose tissue in mice and rats rendered obese by high-fat diet. $J$. Clin. Invest. 51:2907-2915.

20. Roche, A. F. 1981. The adipocyte-number hypothesis. Child Dev. $52: 31-43$

21. Jung, R. T., M. I. Gurr, M. P. Robinson, and W. P. T. James. 1978. Does adipocyte hypercellularity in obesity exist? Br. Med. J. 2: 319-321.

22. Lewis, D. S., H. A. Bertrand, E. J. Masoro, H. C. McGill, Jr., K. D. Carey, and C. A. McMahan. 1983. Preweaning nutrition and fat development in baboons. J. Nutr. 113:2253-2259.

23. McGill, H. C., Jr., C. A. McMahan, A. W. Kruski, and G. E. Mott. 1981. Relationship of lipoprotein cholesterol concentrations to experimental atherosclerosis in baboons. Arteriosclerosis. 1:3-12.

24. Di Girolamo, M., S. Mendlinger, and J. W. Fertig. 1971. A simple method to determine fat cell size and number in four mammalian species. Am. J. Physiol. 221:850-858.

25. Stiles, J. W., A. A. Francendese, and E. J. Masoro. 1975. Influence of age on size and number of fat cells in the epididymal depot. Am. J. Physiol. 229:1561-1568.

26. Hirsch, J., and E. Gallian. 1968. Methods for the determination of adipose cell size in man and animals. J. Lipid Res. 9:110-119.

27. Lavau, M., C. Susini, J. Knittle, S. Blanchet-Hirst, and M. R. C. Greenwood. 1977. A reliable photomicrographic method for determining fat cell size and number: application to dietary obesity. Proc. Soc. Exp. Biol. Med. 156:251-256.

28. Masoro, E. J. 1967. Skeletal muscle lipids. III. Analysis of the functioning of skeletal muscle lipids during fasting. J. Biol. Chem. 242: 1111-1114.

29. Draper, N. R., and H. Smith. 1966. Applied Regression Analysis. John Wiley \& Sons, New York. 1-407 pp.

30. Huber, P. J. 1977. Multiparameter problems. Robust Statistical Procedures. Society for Industrial and Applied Mathematics, Philadelphia. $35-40$.

31. Schrader, R. M., and T. P. Hettmansperger. 1980. Robust analysis of variance based upon a likelihood ratio criterion. Biometrika. 67:93101.

32. Czajka-Narins, D. M., and J. Hirsch. 1974. Supplementary feeding during the preweaning period. Effect on carcass composition and adipose tissue cellularity of the rat. Biol. Neonate. 25:176-185.

33. Brook, C. G. D. 1972. Evidence for a sensitive period in adiposecell replication in man. Lancet. ii:624-627.

34. Gurr, M. I., R. T. Jung, M. P. Robinson, and W. P. T. James. 1982. Adipose tissue cellularity in man: the relationship between fat cell size and number, the mass and distribution of body fat and the history of weight gain and loss. Int. J. Obesity. 6:419-436.

35. Björntorp, P., M. Karlsson, and P. Pettersson. 1982. Expansion of adipose tissue storage capacity at different ages in rats. Metab. Clin. Exp. 31:366-373.

36. Björntorp, P. 1981. Adipocyte precursor cells. In Recent Advances in Obesity Research, vol. III. P. Björntorp, M. Cairella, and A. N. Howard, editors. John Libbey and Co. Ltd., London. 58-69.

37. Glassman, D. M., A. M. Coelho, Jr., K. D. Carey, and C. A. Bramblett. 1984. Weight growth in savannah baboons: a longitudinal study from birth to adulthood. Growth. 48:425-433.

38. Brasel, J. A. 1982. Changes in body composition during adolescence. Curr. Concepts Nutr. 11:13-18.

39. Krotkiewski, M., P. Björntorp, L. Sjöstrom, and U. Smith. 1983. Impact of obesity on metabolism in men and women. Importance of regional adipose tissue distribution. J. Clin. Invest. 72:1150-1162.

40. Smith, U., M. DiGirolamo, G. Blohmé, J. G. Kral, and L.-E. Tisell. 1980. Possible systemic metabolic effects of regional adiposity in a patient with Werner's syndrome. Int. J. Obesity. 4:153-163.

41. Björntorp, P., A. Gustafson, and B. Persson. 1971. Adipose tissue fat cell size and number in relation to metabolism in endogenous hypertriglyceridemia. Acta Med. Scand. 190:363-367.

42. Björntorp, P., A. Jonsson, and P. Berchtold. 1972. Adipose tissue cellularity in maturity onset diabetus mellitus. Acta Med. Scand. 191: 129-132.

43. Kissebah, A. H., N. Vydelingum, R. Murray, D. J. Evans, A. J. Hartz, R. K. Kalkhoff, and P. W. Adams. 1982. Relation of body fat distribution to metabolic complications of obesity. J. Clin. Endocrinol. Metab. 54:254-260. 